\title{
Long-term follow-up of left ventricular systolic function and functional status following Bentall procedure
}

\author{
O Djokic ${ }^{*}$, P Otasevic, S Micovic, S Tomic, I Petrovic, P Dabic, P Milojevic, B Djukanovic \\ From 23rd World Congress of the World Society of Cardio-Thoracic Surgeons \\ Split, Croatia. 12-15 September 2013
}

\section{Background}

Data are scarce on long-term effects of Bentall procedure on left ventricular systolic function and functional status. Aim was to assess long-term effects of Bentall procedure on left ventricular (LV) systolic function and functional status.

\section{Methods}

Study group consisted of 90 consecutive patients who were operated using elective Bentall procedure for the aneurysm of the ascending aorta and aortic valve disease from 1997 to 2003 in a single tertiary care center. Patients were followed for eight years for mortality, LV ejection fraction and volume indices, as well as functional capacity as assessed by NYHA class. Echocardiographic measurements were made according to the recommendations given by the American Society of Echocardiography.

\section{Results}

Study group consisted of 71 male and 19 female patients, mean age $54+/-10$ years. There were no operative deaths. Survival rate was $73.3 \%$ during eight-year follow-up (11 cardiac and 13 non-cardiac deaths). Echocardiography was performed before index procedure and after 96 $+/-9$ months. Statistically significant improvement in the LV ejection fraction was noted at follow-up examinations as compared to preoperative values $(49.4+/-10.2 \%$ vs 42.5 $+/-10.9 \%$, respectively, $\mathrm{p}<0.0001)$. Similarly, statistically significant reduction in the $\mathrm{LV}$ end-systolic $(36.4+/-8 \mathrm{ml}$ vs $59.2+/-29.1 \mathrm{ml}$, respectively, $\mathrm{p}<0.0001)$ and end-diastolic volumes $(70.7+/-18.1 \mathrm{ml}$ vs $101.4+/-32.1 \mathrm{ml}$, respectively, $\mathrm{p}<0.0001)$ were observed. NYHA class improved

* Correspondence: oljaisara@gmail.com

Dedinje Cardiovascular Institute, Belgrade, Serbia from baseline during the follow-up (3.1+/-0.8 vs $1.7+/-1.1$, respectively, $\mathrm{p}<0.0001)$. Univariate analysis identified ejection fraction on admission and the presence of postoperative complications as predictors of long-term LV ejection fraction.

\section{Conclusion}

Bentall procedure significantly improves long-term LV systolic function and functional status.

Published: 11 September 2013

doi:10.1186/1749-8090-8-S1-017

Cite this article as: Djokic et al:: Long-term follow-up of left ventricular systolic function and functional status following Bentall procedure. Journal of Cardiothoracic Surgery 2013 8(Suppl 1):017.
Submit your next manuscript to BioMed Central and take full advantage of:

- Convenient online submission

- Thorough peer review

- No space constraints or color figure charges

- Immediate publication on acceptance

- Inclusion in PubMed, CAS, Scopus and Google Scholar

- Research which is freely available for redistribution

Submit your manuscript at www.biomedcentral.com/submit
() Biomed Central 